\title{
Does Gender Matter? University Library Access and Career Preparedness
}

\author{
Daniella Smith \\ University of North Texas
}

\begin{abstract}
The purpose of this exploratory study was to examine how the gender of distance learning students related to variables such as the perception of the availability of library resources, technology available at home and work, technology provided by a university for distance learning, and career preparedness. A total of 166 master's students in the last semester of their degree program submitted answers to a selfadministered online survey designed to collect information about their degree program experiences. The results of the study indicated that female students felt more prepared by their degree programs when they felt library resources were accessible. Females were also more likely to feel library materials were available if they believed the university's distance learning technology was reliable and that web-based technology provided by the university was adequate. Both genders were more likely to feel they had access to library resources when they felt they had adequate information technology at home or work. Based on these results, it is recommended that faculty collaborate with librarians to market library services so that students are aware of the resources that are available to them. Moreover, implementing strategies such as differentiated learning and optional gender-based library training sessions that utilize learning styles preferred by each gender may be beneficial for students.
\end{abstract}

\section{Introduction}

In an article discussing gender in relation to information needs and services, Ingold and Searing (2007) posed the question of whether gender is still a topic worth discussing. The conclusion was that the topic remains relevant. While many would argue we live in a postfeminist era (Anderson, 2015), Ingold and Searing (2007) assert that gender inequality still exists and that gender continues to evolve beyond the absolute categories of male and female. Despite the continuing evolution of the topic, gender issues are 
frequently not given adequate attention because they are embedded within larger topics, such as multiculturalism and diversity. In respect to higher education, addressing gender, especially its evolution and how it relates to the provision of library services, can help students to thrive within culturally diverse work environments (Mehra \& Braquet, 2007).

Just as the topic of gender continues to evolve, so have the services provided by academic libraries. Today libraries are more than just physical spaces (Loertscher, 2014). Academic libraries supplement face-to-face facilities by offering a plethora of distance learning services that include interlibrary loan, online workshops, and access to e-resources.

The role of academic libraries in the success of students is often overlooked. Yet students entering undergraduate and graduate studies are expected to have proficient information literacy skills. These expectations were delineated in a study conducted to examine the skills that college faculty felt that students need when they start college (Intersegmental Committee of the Academic Senates, 2002). Research skill expectations included the ability to develop hypotheses and concisely express opinions and the capability to identify, appraise, and synthesize information from a variety of resources. These resources can include observations, relevant experiences, printed text, and materials from the Internet. Many of the materials that students need and instruction on how to access them are available in academic libraries.

Irrespective of their location, library services are essential for the success of students. Research shows that the aptitude to conduct research (Latham \& Gross, 2011) and use of the library (Nackerud, Fransen, Peterson, \& Mastel, 2013; Samson, 2014; Wong \& Webb, 2011) have an impact on the academic success of college students. Both distance learning students and traditional face-to-face students need access to quality library services.

\section{Literature Review}

\section{How Students Use the Library}

One way to insure that students have quality academic library services is to study the research behaviors of students and the library services that they use. Samson (2014) studied library e-resource usage by student status. She found that seniors used e-resources more often than any other student population on campus, followed by graduate students. Male and female students on campus used eresources at similar rates. Female students who were off campus used e-resources more frequently than males.

Nackerud et al. (2013) conducted a similar study to examine the types of library services university students were accessing. In the results, they noted that graduates were more heavily dependent on library materials than undergraduate students. The services that were the least used by undergraduate and graduate students were reference materials and instructional activities. The access point that was most used was digital resources. Digital resources were defined as e-journals, e-books, the library's website, and licensed online indexes. A majority of the undergraduate and graduate students did not use circulation services, such as interlibrary loan. Nackerud et al. (2013) also concluded that undergraduate students who used the library at least one time during the semester had higher semester GPAs than students who did not.

Simmonds and Andaleeb (2001) concluded that students who are more familiar with an academic library are more likely to use it. Results of their study suggest that library usage can be increased by employing friendly, experienced staff who provide ongoing training to students. Another key finding in the study was that a student's perception of the quality of a library's materials influences how much a student will use the library, and "access to resources may in fact be seen as vital to judging resource adequacy” (Simmonds \& Andaleeb, 2001, p. 633). The results further suggest that students need to be informed about the availability of resources that can be accessed remotely. Even though students may be attempting to use online resources, basic library instruction is frequently not retained and is not enough to help students understand how to navigate complex database interfaces. It is further stressed that many 
students believe that all of the information that is relevant to their assignments can be found on the Internet. As such, librarians need to teach students how to analytically evaluate information.

\section{Genders and Library Usage}

For many people, the public library is the first type of library they use. Public libraries often provide free educational programs that introduce patrons to information literacy skills. Despite their role in providing continuing education options, Applegate (2008) observed that there is very little research that examines the differences between how adult males and females use the library. In her study conducted in a public library setting with 1,083 patrons, she found that women reported that they used more items on average than males (Applegate, 2008). Women were also more likely to feel that the items that they were using were very important. However, men were more likely than females to report that they visited the library more than once per week. Electronic services, such as the library website and e-mail reminders for holds and due dates, were popular with both genders. Men used wireless access and electronic resources more frequently than women.

Applegate's study also concluded that general services and programming were seldom used and that there were no significant differences between how genders used them. General services included "interlibrary loan, reference, business resources, and reader's advisory" (Applegate, 2008, p. 28). Programming services encompassed book discussion groups, Internet classes, movie nights, and programs aimed at adults.

In another study of libraries, Fidishun (2007) examined how women use public libraries and the technology in them. She found that the primary reason women visited the library was to get books. While her participants were avid users of printed books, they also utilized the technology available at the library. The respondents were described as tech-savvy. The majority of the study participants said they were comfortable using the online catalog and used the library's website. When asked if they wanted training for using databases, a majority said yes. Fidishun (2007) concluded that "women are not as aware of what the public library has to offer regarding technological resources as they could be, and that additional marketing or training for patrons on how to use these resources would be helpful” (pp. 340-341).

\section{The Digital Divide}

Fidishun's (2007) and Applegate's (2008) descriptions of library usage inspire questions about why women in their studies were not using various technologies. Was their lack of interest in the resources a result of not having enough information about availability? Did they have fewer technical skills than the men accessing the services? Or was their desire to use the services influenced by society's perceptions of femininity and masculinity? These are all questions related to the digital divide.

There are opposing viewpoints about the status of the digital divide. According to the Pew Research Internet Project study, gender has ceased to be a factor in who uses the Internet (Zickuhr \& Smith, 2012). Instead, factors such as being over 65, lacking a high school education, and having a household income lower than $\$ 20,000$ are negative indicators of Internet usage. Others comment that there is not a digital divide regarding access but a problem in how the Internet is being used among various socioeconomic groups (Ritchtel, 2012).

Researchers like Dixon et al. (2014) propose that the rapid development of digital technology has continued to increase the digital divide. As technology access points continue to change, the gaps between socioeconomic lines have become more prevalent. Individuals are seeking to access the digital tools necessary for them to thrive economically and educationally. Dixon et al. (2014) advise that there is also a gender divide as women continue to lag behind men in terms of owning technology and learning technology skills.

In their study of public libraries, Dixon et al. (2014) found differences in the ways that men and women use libraries. Like Fidishun (2007), they commented that women are more likely to relate books to libraries, while men are more likely to associate computers as well as books with libraries. Because women associate libraries primarily with books, they are less likely to use them for Internet access. Older women tend to express apprehension about technology but use computers when they feel it is necessary. Even though younger women in the study reported being comfortable with computers, they still did not use computers in the library as much as men did. Dixon et al. (2014) concluded that a gap in how genders 
use the Internet in libraries has remained consistent for at least a decade. They suggest that women without Internet access should try to use libraries more to benefit from online access and to serve as role models for children who will need to learn to use technology.

Research further denotes that differences in how the genders use technology go beyond leisure activities and can affect higher education. Lane and Lyle (2011) studied college-level faculty and determined that women frequently say that a lack of time is a barrier to teaching with technology. On the contrary, males did not cite time as a major obstacle. Lane and Lyle (2001) concluded that when controlling for age and the level of technology expertise, gender did not have a significant effect on technology use. The variable that did have the most significant influence was the faculty members' level of technology expertise. Males were probably using technology more because of their level of expertise. The women in the study who had a higher level of confidence when using technology also were more confident with their technology skills. Similarly, Spotts, Bowmann, and Mertz (1997) reported that males are more inclined to express that they have a greater understanding of and more experience with using technology.

\section{Differences in How Genders Learn}

After studying differences in males and females, Rhoads (2004) surmised that the idea that "families and culture create notions of masculinity and femininity and establish gender-specific roles has become commonplace” (p. 3). Rhoads (2004) believes in the more controversial viewpoint that genetic factors, such as hormones and brain structure, contribute to how males and females behave differently. Researchers Gurian and Stevens (2006) support Rhoads' concepts by asserting that structural differences begin impacting learning styles and paces at early ages. For example, as early as four days old, girls spend more time maintaining eye contact with adults than males do. At four months, girls spend more time observing caregivers, while boys tend to fixate on moving objects.

Evidence of differences in males and females has prompted studies to identify specific ways that males and females learn differently in educational settings. Wehrwein, Lujan, and DiCarlo (2007) studied undergraduate physiology students and their preference for visual, auditory, read-write, and kinesthetic presentation modes. They concluded that, "Some students, male or female, may prefer one of the modalities over the others so strongly that they struggle to understand the subject matter unless special care is taken to present it in their preference mode" (p. 155). Otherwise, women preferred information to be shared in a single mode. In contrast, men were able to adjust to multiple modes of presentation. Wehrwein et al. (2007) recommend that instructors be aware of learning styles and try to avoid teaching students using one style of instruction.

Gurian, Stevens, and Daniels (2009b) also summarized differences by noting that females

- can process information more quickly than males,

- are better multitaskers and more tolerant of traditional class settings,

- tend to express themselves verbally,

- $\quad$ are more attuned to their emotions, and

- frequently need to establish and maintain relationships.

On the contrary, males are

- less tolerant of traditional learning environments and need to move around;

- typically enjoy spatial tasks, such as those that are required in science and technology classes, which include fewer sensory details;

- avoid dramatic situations;

- are less likely to hold grudges; and

- are prone to the physical "fight-or-flight" response rather than emotional engagement.

Observations made by Gurian et al. (2009) coincide with research about behavior variances between males and females in distance learning environments. Distance learning requires students to be confident and to willingly participate by asking questions and discussing topics. These activities are not as intuitive when they take place online rather than in a traditional face-to-face setting. Hwang (2010) explained that when women participate in online environments, they frequently seek to form a social 
identity or want to be accepted as part of a group. They also share more personal information during discussions. Men are more focused on self-identity and may dominate discussions with longer posts. Men lean toward sharing facts about assigned topics rather than their own personal information.

\section{Purpose}

Distance learning offers students more flexibility for pursuing their education than traditional learning does. Yet it is not without its challenges. The ability to use technology has an impact on the academic success of distance learning students. Sanhin and Shelley (2008) assert that students who are comfortable with technology and believe in the value of distance education will adapt better to distance learning. They also note that faculty can prepare their students for class by helping them to understand the technology that will be used during their courses. Moreover, students are more satisfied with faculty when the technology used in class functions properly (Bentley, Shegunshi, \& Scannell, 2010). Library services for distance learning students heavily depend on technology. Students must be aware of library services and how to use the technology that they rely upon to properly access services.

Given the examples of the differences in how genders learn (Gurian et al., 2009b; Wehrwein, et al., 2007), the variances in how males and females use libraries (Applegate, 2008; Dixon et al., 2014; Samson, 2014), and the impact of library usage on academic success (Latham \& Gross, 2011; Nackerud et al., 2013; Samson, 2014; Wong \& Webb, 2011), the purpose of this study is to explore how gender relates to variables such as library service usage, perceptions of the availability of library resources, opinions of technology suitability and reliability, and attitudes regarding career preparation. This information is important because it makes an effort to understand the significance of library services for distance learning students. Accounting for gender in relation to these variables is a vital component of addressing the multidimensional needs of students and delivering quality distance learning programs. The following research questions were used to implement the study:

1. What types of library services do male and female students enrolled in distance learning use?

2. Is there a relationship between how male and female students enrolled in distance learning perceive career preparedness and the accessibility of library resources?

3. Is there a relationship between how male and female students enrolled in distance learning perceive the suitability of the technology available at home and work and the availability of university library services?

4. Is there a relationship between how male and female students enrolled in distance learning perceive the accessibility of library resources and the reliability of the university's distance learning technology?

5. Is there a relationship between how males and females enrolled in distance learning perceive the accessibility of library resources and the provision of adequate access to web-based technology?

\section{Methods}

\section{Data Collection}

During the fall 2013 and spring 2014 semesters, a total of 232 students who attended a university in the midwestern United States were invited to participate in an online self-administered survey designed to assess students' satisfaction with their degree program experience. The students were in their last semester of their online master's degree program. A purposive sample of 166 students returned surveys with gender information included. There were 140 females and 26 males. The subset of questions used for this report addressed library services and perceptions of technology.

The students were asked how often they used particular library services. Next, they were asked to use a Likert scale to rate

- their feelings of career preparedness,

- the availability of library services from the university,

- the reliability of the university's distance learning technology,

- the university's provision of adequate web-based technology, and

- the suitability of the technology they had at home and/or work. 
As distance learning students, the participants of this study were expected to have adequate access to technology such as a computer, appropriate software, and an Internet connection either at work or at home. For the purposes of this study, the web-based technology provided by the university includes the technological infrastructure, such as the software, databases, websites, and course management system, used to facilitate learning. Library resources included services such as interlibrary loan, access to online and print materials, reference services, and instruction.

The data was imported into SPSS. The survey results were coded by gender. After the genders were coded, personal identification information was removed. Then the results were divided into gender groups. Each gender group was analyzed separately to determine whether the variables had a relationship with gender. Responses to Research Question 1 were examined by calculating the mean for each response. Research Questions 2, 3, 4, and 5 were analyzed by performing the Spearman rank correlation to test the relationships between the variables.

\section{Limitations}

This study has limitations. The survey instrument used to collect data was not developed to specifically study perceptions of library services and usage. In addition, demographic questions were not a component of the survey. Although limited information was collected about library services, the study is intended to be exploratory in nature, with the objective of implementing an extensive study in the future.

All of the responses used for this report were quantitative. In the future, qualitative responses from open-ended questions, interviews, and focus groups will be used to supplement quantitative responses and allow triangulation of data (Creswell \& Plano Clark, 2007). This study is a work in progress and is currently limited to a purposive sample that is not representative of the entire student population of the university studied. While the results are informative, they are not generalizable.

The selected majors of students who participated in this study present another limitation, for all participants were engaged in completing a degree program allowing them to major in either library science or information science. Though both majors are often taught within a single department, they differ in scope. While library science is "the professional knowledge and skill with which recorded information is selected, acquired, organized, stored, maintained, retrieved, and disseminated to meet the needs of a specific clientele" (Reitz, 2004, p. 415), information science is the "systematic study and analysis of the sources, development, collection, organization, dissemination, evaluation, use and management of information in all its forms, including the channels (formal and informal) and technology used in its communication” (Reitz, 2004, p. 358).

Library science lacks an aspect of diversity. Men account for only $12 \%$ of librarians; in fact, most librarians are Caucasian women (American Library Association, 2012). By contrast, information science is perceived as more technical and attracts more men. Hildenbrand (1999, p. 673) has remarked that there may be some truth to the statement that "information science is library science for boys," as men tend to assume more computer-oriented positions within information organizations. It has also been noted that men typically teach information science courses, while women frequently teach those of library science (Gorman, 2004).

In sum, the dynamics between (a) what is entailed in study of library science versus information science, (b) how their respective courses are taught, and (c) the majors selected by students may have contributed to the differences in the perceptions of the men and women who participated in this study. Although the participants were not asked to identify their majors, a majority of students that enroll in the described degree program pursue degrees in library science. More women participated than men, likely owing to the fact that women dominate library science.

\section{Results}

\section{Research Question 1}

Each student was asked what type of library materials they accessed. The resources accessed by each gender during their degree program were similar. (See Table 1.) A majority of both males (61.6\%) 
and females (60.7\%) reported that the printed materials available from the university's library were not applicable, never used, or not available. Yet a majority of males (69.2\%) and females (57.2\%) used printed materials available at other libraries. All of the participants said that they frequently (males: 92.3\%, females: $93.6 \%$ ) or moderately (male: $7.7 \%$, female: $6.4 \%$ ) used the library website and electronic resources provided by the university. Most of the participants (males: $88.5 \%$, females: $77.9 \%$ ) also used other libraries' websites and electronic resources. Nonlibrary web-based resources were popular too. The results indicated that most males (92.4\%) and females (90.0\%) used materials from the Internet to assist them with completing their assignments. One difference between the male and female responses was that females selected that various materials were "not applicable" or "not available" more often than males.

\begin{tabular}{|c|c|c|c|c|c|c|c|c|c|c|}
\hline \multirow[t]{2}{*}{ Source of materials } & \multicolumn{2}{|c|}{ Frequent use } & \multicolumn{2}{|c|}{ Moderate use } & \multicolumn{2}{|c|}{ Not applicable } & \multicolumn{2}{|c|}{ Never used } & \multicolumn{2}{|c|}{ Not available } \\
\hline & Male & Female & Male & $\begin{array}{l}\text { Femal } \\
\mathrm{e}\end{array}$ & Male & $\begin{array}{l}\text { Femal } \\
\mathrm{e}\end{array}$ & Male & $\begin{array}{l}\text { Femal } \\
\mathrm{e}\end{array}$ & Male & Female \\
\hline $\begin{array}{l}\text { University printed } \\
\text { library resources }\end{array}$ & $\begin{array}{l}11.5 \\
\%\end{array}$ & $6.4 \%$ & $26.9 \%$ & $\begin{array}{l}32.9 \\
\%\end{array}$ & $11.5 \%$ & $\begin{array}{l}22.1 \\
\%\end{array}$ & $\begin{array}{l}46.2 \\
\%\end{array}$ & $\begin{array}{l}35.7 \\
\%\end{array}$ & $\begin{array}{l}3.9 \\
\%\end{array}$ & $2.9 \%$ \\
\hline $\begin{array}{l}\text { University library } \\
\text { website and electronic } \\
\text { resources }\end{array}$ & $92.3 \%$ & $93.6 \%$ & $7.7 \%$ & $6.4 \%$ & - & - & - & - & - & - \\
\hline $\begin{array}{l}\text { Other libraries' printed } \\
\text { library resources }\end{array}$ & $\begin{array}{l}26.9 \\
\%\end{array}$ & $8.6 \%$ & $\begin{array}{l}42.3 \\
\%\end{array}$ & $\begin{array}{l}48.6 \\
\%\end{array}$ & - & $\begin{array}{l}13.6 \\
\%\end{array}$ & $\begin{array}{l}30.8 \\
\%\end{array}$ & $\begin{array}{l}27.9 \\
\%\end{array}$ & - & $1.3 \%$ \\
\hline $\begin{array}{l}\text { Other libraries' websites } \\
\text { and electronic resources }\end{array}$ & $\begin{array}{l}34.6 \\
\%\end{array}$ & $21.4 \%$ & $\begin{array}{l}53.9 \\
\%\end{array}$ & $\begin{array}{l}56.5 \\
\%\end{array}$ & - & $1.4 \%$ & $\begin{array}{l}11.5 \\
\%\end{array}$ & $\begin{array}{l}18.6 \\
\%\end{array}$ & - & $2.1 \%$ \\
\hline $\begin{array}{l}\text { Nonlibrary } \\
\text { materials }\end{array}$ & $\begin{array}{l}15.4 \\
\%\end{array}$ & $19.3 \%$ & $\begin{array}{l}77.0 \\
\%\end{array}$ & $70.7 \%$ & - & $1.4 \%$ & $7.6 \%$ & $7.9 \%$ & - & $0.7 \%$ \\
\hline
\end{tabular}

\section{Research Question 2}

A Spearman rank correlation was conducted to analyze the relationship between how the participants perceived career preparedness and the accessibility of library resources. The results indicated that there was a significant positive relationship between the variables for female students $\left(r_{s}=.384, n\right.$ $=140, p=.000$ ). Female students felt more prepared by their degree programs when they felt library resources were available for them to access. A significant relationship between the variables was not found for males.

\section{Research Question 3}

A Spearman rank correlation was run to investigate the relationship between how the participants perceived the suitability of the technology available at home and work and the availability of university library services. Statistically significant positive correlations were found between the variables for females $\left(r_{s}=.416, n=140, p=.000\right)$ and males $\left(r_{s}=.517, n=26, p=.007\right)$. Both genders were more likely to feel they had access to library resources when they felt they had adequate information technology at home or work.

\section{Research Question 4}

A Spearman rank correlation was used to determine the relationship between how the participants perceived the accessibility of library resources and the reliability of the university's distance learning technology. The results indicated that while there was no significant relationship between the variables for males, there was a positive significant relationship between them for females $\left(r_{\mathrm{s}}=.391, n=140, p=\right.$ .000). Females were more likely to feel library materials were available if they felt the university's distance learning technology was reliable.

\section{Research Question 5}

A final Spearman rank correlation was implemented to examine the relationship between how the participants perceived the accessibility of library resources and the provision of adequate access to web- 
based technology. Results signified that there was a positive significant relationship between the variables for females $\left(r_{s}=.429, n=140, p=.000\right)$. When the female participants felt they had access to adequate web-based technology, they were more likely to feel that the library had resources available to them. There was no relationship between the variables for men.

\section{Discussion and Recommendations}

\section{Differentiated Learning}

Some researchers state that males and females are genetically different and have different learning styles because of these genetic differences (Rhoads, 2004; Gurian \& Stevens, 2006). The university library and faculty may seek to counteract how females perceive the availability of library services by organizing individualized training opportunities or creating differentiated teaching strategies that appeal to multiple intelligences during training sessions. For example, Wehrwein et al. (2007) advises instructors to create varied lessons in multiple presentation modes to enable students to experience lessons in the presentation mode they learn the most from.

Likewise, allowing students to voluntarily opt in to gender-specific online library training sessions is another strategy that can be explored. In recent years, there has been a resurgence of K-12 schools that offer single-sex classrooms for specific topics or schools that are dedicated to serving one gender (Gurian et al., 2009a). Though this study focuses on graduate students, Gurian et al. (2009b) state that these initiatives have been beneficial to students because lessons are developed using teaching strategies that are conducive to each gender's learning style. In the case of bibliographic instruction, females may enjoy training sessions designed to be more social. Alternatively, males may appreciate focused training that involves less interaction.

\section{Library Anxiety}

Another possible factor that may have an impact on the correlation between library services and career preparedness for females could be library anxiety. Library anxiety is characterized by negative feelings toward library environments that can adversely affect library usage (Onwuegbuzie, Jiao, \& Bostick, 2004). Library anxiety is a serious condition among college students because of the requirement that students conduct library research. The information search process (ISP) often causes individuals to experience anxiety, and the complexity of the process should not be overlooked as a contributing factor to this anxiety (Kuhlthau, 1991). Kuhlthau (2010) asserts that, regardless of their ability to use computers, it is still important for individuals to be taught information literacy skills, such as finding resources, discerning credibility, and synthesizing information. The inability to complete research or the ISP can have a negative impact on student grades (Nackerud et al., 2013; Samson, 2014; Wong \& Webb, 2011).

Although females are more likely to ask for help, they are also prone to remembering negative situations (Gurian et al., 2009b). Library anxiety related to previous unfavorable experiences with databases, physical libraries, or library staff may influence how females utilize online library resources. It can be inferred that if women experience this anxiety at some point during their education, they may avoid using library resources in the future or feel that the library does not have the resources that they need.

\section{Library Usage}

There were some similarities between how the students in this study used library resources and the results reported by Applegate (2008), Nackerud et al. (2013), and Samson (2014). Like Samson's (2014) students, males and females in this study used e-resources at similar rates. However, females were not using them at a higher percentage than males. The results in this study resembled Nackerud et al.'s (2014) finding that electronic resources were used the most. This result was expected because this study included only online students. The use of interlibrary loan by the students was comparable to Applegate's (2008) and Nackerud et al.'s (2013) summaries. These services were included in access to print resources and were not popular. This is a result that is consistent for both males and females and does not appear to be related to gender. 


\section{Evaluating Technology Skills}

The results of Research Question 3 were expected. Participants in both genders had similar feelings with regard to the relationship between the availability of technology in their homes or at work and the availability of library resources. Because this relationship was significant for both males and females, the results seem to support Zickuhr and Smith's (2012) results indicating that the gender gap in the digital divide is closing.

Yet the results of Research Questions 4 and 5 are reminders that online library services are highly technical and require students to have suitable, up-to-date computers to access them. The results also indicate that female students' perceptions of the availability of library resources are negatively impacted when they do not believe the university's technology is reliable or the university does not provide adequate access to web-based technology. Students with inadequate browsers or slow Internet connections may find it difficult to navigate databases, which can be complex (Simmonds \& Andaleeb, 2001). Since students may not understand when they lack appropriate information literacy skills (Latham \& Gross, 2011), they may be associating their skill deficiencies and the frustration they feel when completing research with web-based technology errors. Whether this is occurring will not become clear until a multimethod study is implemented.

In the meantime, one way that universities can ensure that students are prepared for the rigors of online learning would be to assess their technology skills and equipment prior to their starting degree programs. Students can be counseled about appropriate software and hardware, discounts for computers, and how to locate alternative solutions for accessing technology. One may deduce that being proactive about students' technology skills and access to technology may increase their academic success by helping them to acquire the technology skills, software, and hardware that will be required to access library services online. This observation concurs with Bentley et al.'s (2010) finding that students are more satisfied with instructors when technology for class is in working order.

\section{Assessing Information Literacy Skills}

Many graduate students who enroll in distance learning programs are nontraditional students returning to college after extended breaks between degree programs. Nontraditional students frequently are older learners who may not have been required to use online databases prior to returning to school. Moreover, many students are not aware that they have an information literacy skill deficiency (Latham \& Gross, 2011) or do not understand that using the library improves academic success (Nackerud et al., 2013; Samson, 2014; Wong \& Webb, 2011). Coupling these issues with the results of this study leads me to recommend that schools begin assessing the information literacy skills of online degree program candidates.

\section{Marketing Library Materials}

Despite evidence of the closing gender gap, there are results in this study that nonetheless have implications for women. Females were more likely than males to say that various materials were not available. The selection of some choices by females warrants further investigation into the reasons females may perceive that resources are not available or applicable to them.

Library services may seem inadequate, unavailable, or inapplicable if a student does not understand how to access them or the reasons the student should access a particular library service. Interlibrary loan was an example of a library service that was overlooked by the participants. The university that the students in this study attended has an extensive collection of printed books and journals. Distance learning students could access these materials and others available through the library's consortium by requesting them, but students will not benefit from such services if they are not aware that these materials are available.

There is a need for university faculty and librarians to collaborate to make students aware of library services, because students are more likely to interact with faculty than librarians. Informing students about available library programs will increase their use (Simmonds \& Andaleeb, 2001). Faculty can improve students' perceptions of library services and the adequacy and reliability of technology available from the university by promoting their benefits. These results suggest that educating students about library services is particularly essential for female students, who may not feel prepared for their 
careers upon the completion of their programs when library materials are not perceived to be readily available.

\section{Conclusion}

The findings presented in this article provide only a snapshot of the underlying issues that may cause distance learning students to question the availability of library services, the adequacy and reliability of university technology support structures, and their own career preparedness. The results provide evidence that the availability of the technology that distance learning students use to complete their degree programs can have an impact on their perceptions of the availability of library resources. Therefore, distance learning students need skill assessments to determine whether they have access to appropriate technology and have developed essential technology skills.

In addition, the students in this study majored in either library science or information science. It is logical for graduating library science students to want to feel like they can effectively use a library when they begin their careers. Similarly, information literacy skills, such as the ability to navigate databases, can be considered technical in nature. Comparable to library science majors, information science students need to feel that they are competent users of information.

Regardless of the majors that students select, library training is needed at the beginning of distance learning programs for all students to counteract misunderstandings about the accessibility of library materials. According to the results of this study, women in particular are more susceptible to feeling their degrees did not prepare them when they believe library services are not accessible. It is possible that library orientation sessions would make them feel more empowered. The benefits of using technology available in the library should be described to women because of how women use libraries and technology available within them (Fidishun, 2007; Terry \& Gomez, 2011). Differentiated workshops based on gender or learning styles may provide training options that are attractive to both genders.

This exploratory study answered several questions, yet it exposed several more that need to be researched. It must be acknowledged that correlations should not be confused with causation. An in-depth multimethod study with additional participants is needed. There are also factors such as library anxiety, the impact of selected majors, international student status, levels of information literacy skills, and library and technology proficiency that should be explored. In addition, the topic of gender now reaches beyond males and females. This study did not account for students that are transgendered or transsexual. This is an emerging topic that will provide additional insight into an issue that requires in-depth analysis before universities can fully serve the needs of all students.

\section{References}

American Library Association. (2012). Diversity counts. Retrieved from http://www.ala.org/offices/sites/ala.org.offices/files/content/diversity/diversitycounts/diversitycou ntstables2012.pdf

Anderson, K. J. (2015). Modern misogyny: Anti-feminism in a post-feminist era. New York, NY: Oxford University Press.

Applegate, R. (2008). Gender differences in the use of a public library. Public Library Quarterly, 27(1), 19-31. doi: http://dx.doi.org/10.1080/01616840802122468

Bentley, Y., Shegunshi, A., \& Scannell, M. (2010). Evaluating the impact of distance learning support systems on the learning experience of MBA students in a global context. Electronic Journal of ELearning, 8(2), 51-62. 
Creswell, J. W., \& Plano Clark, V. L. (2007). Designing and conducting mixed methods research. Thousand Oaks, CA: Sage Publications.

Dixon, L. J., Correa, T., Straubhaar, J., Covarrubias, L., Graber, D., Spence, J., \& Rojas, V. (2014). Gendered space: The digital divide between male and female users in Internet public access sites. Journal of Computer-Mediated Communication, 19(4), 991-1009. http://dx.doi.org/10.1111/jcc4.12088

Fidishun, D. (2007). Women and the public library: Using technology, using the library. Library Trends, 56(2), 328-343. doi: http://dx.doi.org/10.1353/lib.2008.0010

Gorman, M. (2004). Whither library education? New Library World, 105(9), 376-380.

Gurian, M., \& Stevens, K. (2006). How boys learn. Educational Horizons, 84(2), 87-93.

Gurian, M., Stevens, K., \& Daniels, P. D. (2009a). Single-sex classrooms are succeeding. Educational Horizons, 87(2), 234-245.

Gurian, M., Stevens, K., \& Becker, P. D. (2009b). Successful single-sex classrooms: A practical guide to teaching boys and girls separately. San Francisco, CA: Jossey-Bass.

Hildenbrand, S. (1999). The information age versus gender equity? Technology and values in education for library and information science. Library Trends, 47(4), 669-685.

Ingold, C., \& Searing, S. E. (2007). Introduction: Gender issues in information needs and services. Library Trends, 56(2), 299-302. doi: http://dx.doi.org/10.1353/lib.2008.0012

Intersegmental Committee of the Academic Senates. (2002). Academic literacy: A statement of competencies expected of students entering California's public colleges and universities. Retrieved from http://icasca.org/Websites/icasca/Images/Competency/AcademicLiteracy2002.pdf

Kuhlthau, C. C. (1991). Inside the search process: Information seeking from the user's perspective. Journal of the American Society for Information Science (1986-1998), 42(5), 361.

Latham, D., \& Gross, M. (2011). Enhancing skills, effecting change: Evaluating an intervention for students with below proficient information literacy skills. Canadian Journal of Library and Information Sciences, 35(4), 367-383.

Loertscher, D. (2014). Climbing to excellence: Defining characteristics of successful learning commons. Retrieved

from http://www.ala.org/aasl/sites/ala.org.aasl/files/content/aaslpubsandjournals/knowledgequest/docs/ KQ_MarApr14_ClimbingtoExcellence.pdf

Mehra, B., \& Braquet, D. (2007). Library and information science professionals as community action researchers in an academic setting: Top ten directions to further institutional change for people of diverse sexual orientations and gender identities. Library Trends, 56(2), 542-565. doi: http://dx.doi.org/10.1353/lib.2008.0005

Nackerud, S., Fransen, J., Peterson, K., \& Mastel, K. (2013). Analyzing demographics: Assessing library use across the institution. Portal: Libraries and the Academy, 13(2), 131-145. doi: http://dx.doi.org/10.1353/pla.2013.0017 
Onwuegbuzie, A. J., Jiao, Q. G., \& Bostick, S. L. (2004). Library anxiety: Theory, research, and applications. Lanham, MD: Scarecrow Press.

Rhoads, S. E. (2004). Taking sex differences seriously. San Francisco, CA: Encounter Books.

Reitz, J. M. (2004). Dictionary for library and information science. Westport, Connecticut: Libraries Unlimited.

Ritchel, M. (2012, May 29). Wasting time is the new divide in the digital era. New York Times. Retrieved from http://www.nytimes.com/2012/05/30/us/new-digital-divide-seen-in-wasting-timeonline.html?pagewanted=1\& r=0\&adxnnl=1\&adxnnlx=14217013131CgWlEd32DLn84/1F1TplQ

Samson, S. (2014). Usage of E-resources: Virtual value of demographics. The Journal of Academic Librarianship, 40(6), 620-625. doi: http://libproxy.library.unt.edu:2073/10.1016/j.acalib.2014.10.005

Sanhin, I., \& Shelley, M. (2008). Considering students' perceptions: The distance education student satisfaction model. Educational Technology \& Society, 11(3), 216-223.

Simmonds, P. L., \& Andaleeb, S. S. (2001). Usage of academic libraries: The role of service quality, resources, and user characteristics. Library Trends, 49(4), 626-634.

Terry, A., \& Gomez, R. (2011). Gender and public access computing: An international perspective. Retrieved from http://www.computer.org/csdl/proceedings/hicss/2011/4282/00/03-01-02.pdf

Wehrwein, E. A., Lujan, H. L., \& DiCarlo, S. E. (2007). Gender differences in learning style preferences among undergraduate physiology students. Advances in Physiology Education, 31(2), 153-157. doi: 10.1152/advan.00060.2006

Wong, S. H. R., \& Webb, T. D. (2011). Uncovering meaningful correlation between student academic performance and library material usage. College \& Research Libraries, 72(4), 361-370. doi: http://dx.doi.org/10.5860/crl-129

Zickuhr, K., \& Smith, A. (2012). Pew Research Internet project: Digital differences. Retrieved from http://www.pewinternet.org/2012/04/13/digital-differences/ 